László Vértesy

\title{
DEBT MANAGEMENT STRATEGIES OF LOCAL GOVERNMENTS IN THE EU
}

\author{
Helyi önkormányzati adósságkezelési stratégiák az Európai Unióban
}

Dr. habil. László Vértesy PhD jur. PhD oec. associate professor, University of Public Service, Faculty of Public Governance and International Studies, Lőrincz Lajos Department of Administrative Law, vertesy.laszlo@uni-nke.hu

A considerable part of public debt originates from the budgetary practices of local governments: this amounted to nearly 850 billion euros, which was $6.7 \%$ of the EU-28's general government gross debt in 2018. This paper briefly presents the magnitude and relevance of local government debt at a national level, then it outlines the effective debt management strategies taking a multi-level governance approach. Four debt management categories can be classified: changing the conditions, repayment strategies, additional resources and, finally, state intervention. Unfortunately, there are no good/best practices for the first two methods. For additional resources, in some Mediterranean and Scandinavian countries, state or local government-owned specialised financial institutions were established, while in other European countries, the state pays the bailout or consolidation by overtaking the unsustainable local debts. In most cases, only the direct and/or indirect state intervention methods were proven to be successful solutions.

KeYwords:

local government, public debt, debt management

Az államadósság egy meghatározó része az önkormányzatok költségvetési gyakorlatából származik, a közel 850 milliárd euró az EU-28 ország államadósságának 6,7\%-a volt 2018-ban. A tanulmány röviden bemutatja az önkormányzati adósság nagyságát és relevanciáját nemzeti szinten, majd központi gondolata a hatékony adósságkezelési stratégiák elemzése a helyi és központi kormányzati szinteken. Négy adósságkezelési kategóriát lehet elkülöniteni: a feltételek megváltoztatása, a visszafizetési stratégiák, a kiegészitő források és végül az állami beavatkozás. Sajnos az első két módszernél nincs jó vagy legjobb gyakorlat. További források elérése érdekében 
néhány mediterrán és skandináv országban állami vagy önkormányzati tulajdonú szakositott pénzügyi intézményeket hoztak létre. Más európai országokban az állam vállalta a kimentést vagy konszolidációt a fenntarthatatlan helyi adósságok felszámolásával. A legtöbb esetben csak a közvetlen és/vagy közvetett állami beavatkozási módszerek bizonyultak sikeres megoldásoknak.

Kulcsszavak:

önkormányzat, államadósság, adósságkezelés 


\section{INTRODUCTION}

Public debt is still a quotidian topic in economics, most countries worldwide face its management challenges. A distinct part of these burdens originates from the budgetary practices of local governments. According to the European practice, the local government subsystem is part of the general government budget, but it is separated from the central budget; it is linked to the central budget by supports. In some European countries, unsustainable local government debt has emerged as a problem during and after the recent financial crises, as a consequence of the central transfer reductions (Greece, Ireland, Italy, Portugal, Spain, Romania, United Kingdom). ${ }^{1}$

The Maastricht Treaty contains certain provisions on public finances, specifically, Article 126 and 140 of the Treaty on the Functioning of the European Union prescribes that general government debt shall not exceed $60 \%$ of the gross domestic product. This extenuates the economic importance of effective budgetary management of local governments, since their debt also needs to be calculated into the national public debt, according to the unified methodology. ${ }^{2}$

As a generally accepted golden principle - in accordance with the financial autonomy -, the consequences of the loss-making management of the local government are borne by the local government, and the central budget is not responsible for its obligations. Therefore, only the local government is liable for sustainable local finances and debt management. For EU member states this problem has pivotal importance both from a legislative and an economic point of view.

The European Charter of Local Self-Government guarantees the financial selfdetermination of the budget for municipalities, but this autonomy needs to be exercised within clear policies, with prudential macroeconomic limits to borrowing and processes of public scrutiny. Sustainable and reasonable local public finances are important because the burden of the debt service bears not just economic, but a significant political impact within the municipality: the local citizens are not just taxpayers but also voters. Usually the constitutions and/or other fiscal rules regulate these principles.

For the above mentioned reasons, this paper examines numerous effective debt management strategies, taking a multi-governance approach, and showing how responsibilities can be shared between central and local institutions.

Because of the cross-disciplinary nature of the topic, the analysis and evaluation (law and finances), the research is based on a comparative legal and economic methodology. ${ }^{4}$

\footnotetext{
Davey 2011, 43. For non-EU members see NaLAs 2011 (Albania, Bulgaria, Croatia, Kosovo, Macedonia, Moldova, Montenegro, Republika Srpska - BiH, Romania, Serbia and Turkey).

Eurostat 2016; International Monetary Fund 2013.

Nyikos 2013; FinžGAR-BrezovNIK 2019.

SCHNYDER 2016, 45.
} 
The legal method is based on the classical interpretation (grammatical or textual, historical, logical, systematic) of the relevant supranational and for some practical cases the national law sources, which are completed by the teleological and constitution conformity. ${ }^{5}$ For comparison, the EU regulations (e.g. stability pact or debt brake rules) are an important initiation. Besides the legal methodology, the study employs economic ones, especially the quantitative approach. The paper contains some comparative statistics (OECD and Eurostat) to evaluate certain results based on figures because it is important to match the provisions with economic performance. The debt management of local governments can be analysed by positive and normative law and finance (or law and economics), in the case of the latter the outcome of collective choices is considered "fair", "just", or "efficient". For local governments, local self-governments and municipalities the European Union classification assigns them to the lower levels of Local Administrative Units (LAU level 2).

\section{LOCAL GOVERNMENT DEBTS}

The following basics deal briefly with the definition, the subjects and the structure of local debts. Debt means usually something, especially money, that is owed to someone else, or the state of owing something that can be expressed in monetary value. The meaning of money should be interpreted broadly, because local governments prefer in practice loans, bonds, account receivables, notes, and mortgages, which are all typical components of debt.

By subjects, the debt is owed by one party, the borrower or debtor, to a second party, the lender or creditor. The debtors are local governments, local self-governments, municipalities with fiscal autonomy. In the EU classification, it means the lower levels of Local Administrative Units (LAU level 2), which consists of municipalities or equivalent units. Concerning our topic, the owners of the debts, the creditors need to be divided into two main categories according to the type of debt. In the case of local government bonds, they can be anyone: natural persons (citizens), private and public, domestic or foreign, international legal persons. Credits and loans can be provided usually by banks, since this is considered as a business activity. In some Mediterranean and Nordic countries, specialised financial institutions, special-purpose vehicles or so-called local government financing vehicles were established by the state or the municipalities for local government financing.

STELMACH 2006, 148. 


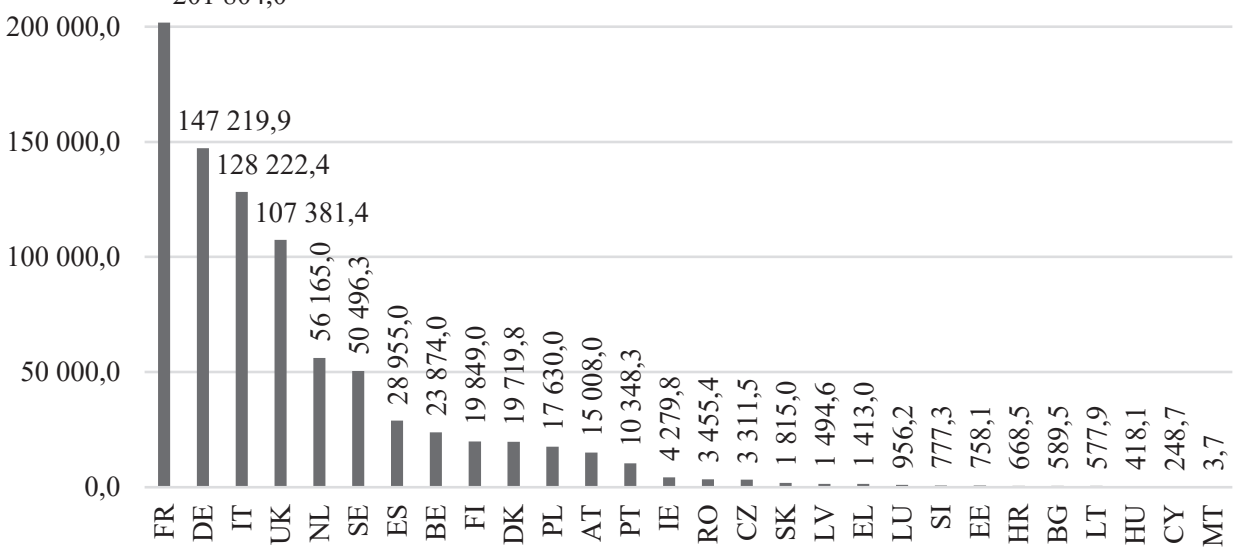

Figure 1 - The amount of local government debts (million euro) (Source: Compiled by the author based on Local government debt, 2018)

The total local debt is worth 847.4 billion euros, the four-fifth of which (81.5\%) belongs to six countries: France (201.8 billion euros, 23\%), Germany (147.2 billion euros, 17\%), Italy (128.2 billion euros, 15\%), the United Kingdom (107.3 billion euros, 12\%), the Netherlands (56.1 billion euros, $7.8 \%$ ) and Sweden (50.4 billion euros, $6.7 \%$ ). In some countries, the local government debt represents a high proportion of the general government debt: in Estonia it is $36 \%$, in Sweden $26 \%$ or in Denmark $18.8 \%$ of the public debt, while in Finland and France it is close to $9 \%$ of the GDP. ${ }^{6}$

According to the characteristic of the local debt, the conditions relate to the amount and timing of repayments of principal and interest. In the case of loans, the lender usually sets up strict provisions, which have a restrictive impact on the local budget. Furthermore, the suitable coverage is also important, which is over and beyond the non marketable or limitedly marketable assets defined by the national legislation. However, it is easier for the local government to borrow a high amount in a short time. The bonds are the other typical debt obligation, for which the conditions are defined unilaterally by the issuing municipality, but it is a slower process to accumulate the necessary amount. Usually, debt or bond financing will not be used to finance current operating expenditures, the purposes of these amounts are local developments, capital investments, constructions, own contribution to other credits or grants. On the other hand, municipalities use short-term debt to make up for uneven cash flows; in some Eastern European countries (for example, in Hungary) local governments borrow(ed) money for short term (1-2 months) to bridge the everyday liquidity difficulties, because of the delay of the supports from the central budget.

VÉRTESY 2019, 618; Local government debt, 2018; Structure of government debt, 2020. 


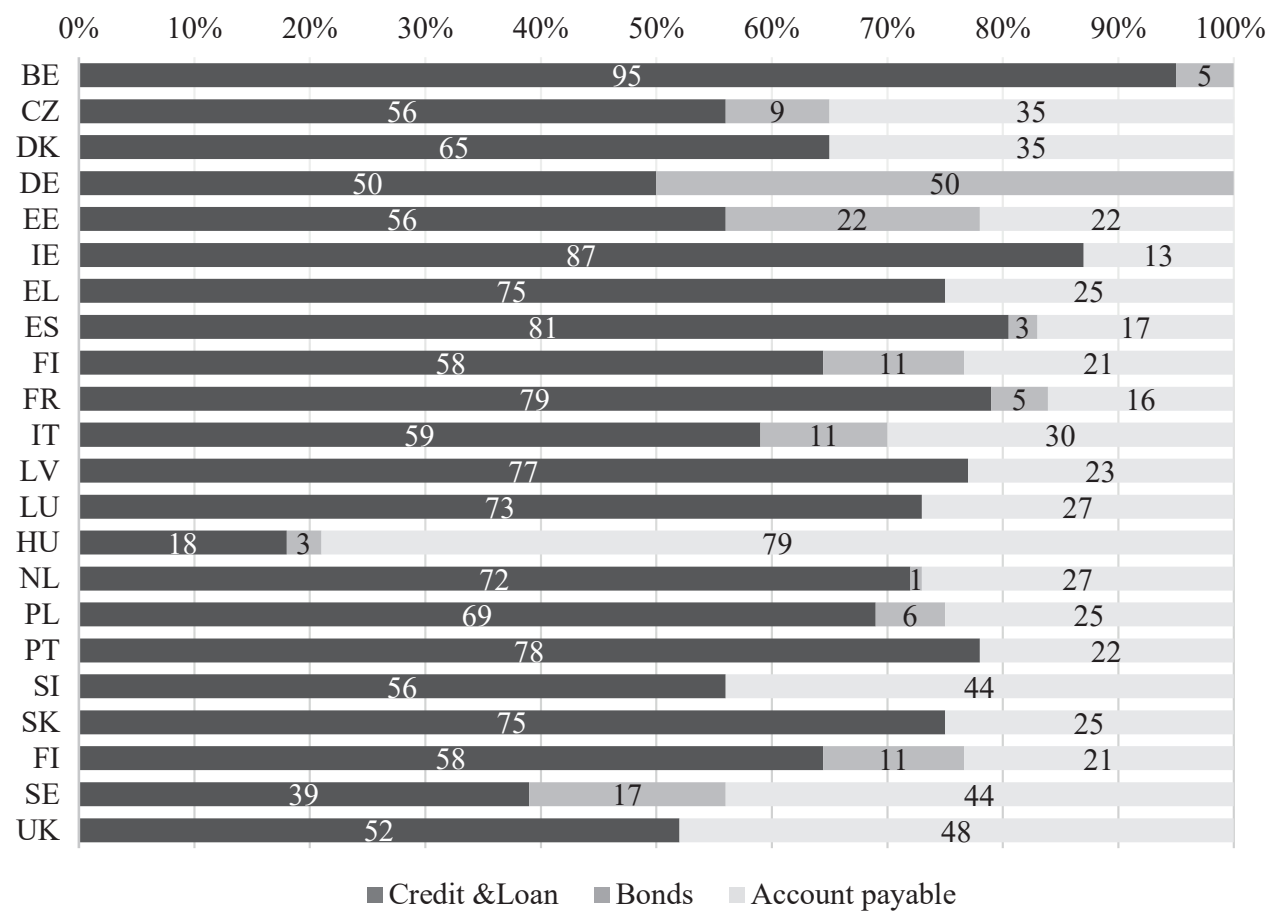

Figure 2 - Structure of local government debts

(Source: Compiled by the author based on OECD 2017.)

In the examined European countries, an overwhelming proportion of the local government debt is denominated in loans, the average is $64.8 \%$. Another significant rate belongs to the accounts payable: $29.5 \%$, and only $11.8 \%$ is in bonds. According to these, it is simpler and easier for municipalities to borrow money from financial intermediaries, especially from the banking sector. ${ }^{7}$ Since there is a lower or no confidence in local bonds and securities, ${ }^{8}$ collecting money directly from the market is more difficult. Sometimes it can be observed that after the local government cannot borrow more money from the banking system, it switches to bonds. ${ }^{9}$ For example, in Hungary, the municipalities owed 1.55 billion euros in loans and only 0.07 billion in bonds, ${ }^{10}$ and by 2010 the debt in bonds ( 2.12 billion euros) was nearly the same amount as credits and bills of exchange (1.96 billion euros). ${ }^{11}$ In Estonia the same situation can be found: the share of loans for municipal outstanding debt accounted

VÉRTESY 2019, 619.

DZigBede 2016, 23-24.

ABADA-ChuliáB-Gómez 2010, 2851-2860.

LentNer-Hegedüs 2019, 22; ACZÉL-Homolya 2011.

LENTNER et al. 2019; the local governments' credit and bonds on the basis of Hungarian local government reports 2005-2013. 
for $56 \%$, that of bonds, $22 \%$, the remaining part is made up of other accounts payable. ${ }^{12}$ A similar trend can be found in China. ${ }^{13}$

It is worth mentioning that not just the indebtedness is the real problem ${ }^{14}$ but rather the financing of it. If the local government faces with a relatively high debt, but it has a balanced budget and enough revenues, resources to pay off the loans and bonds, then the debt, it is just a temporary burden. Under the most favourable circumstances, the debt

- is proportional in size and rate of growth in its tax base;

- does not extend past the useful life of the facilities that it finances;

- is not used to balance the operating budget;

- does not require repayment schedules that put excessive burdens on operating expenditures; and

- is not so high as to jeopardize the credit rating. ${ }^{15}$

\section{DEBT MANAGEMENT STRATEGIES}

The primary purpose of the debt management is redemption, which has many different ways, and it is difficult to generate a best practice suitable for all local governments. ${ }^{16}$ Another objective of it is to minimise the cost of borrowings in the medium or the long run, consistently with a prudent degree of risk. The question is rather complex because several methods and processes can be distinguished which can be applied parallelly, depending on the amount and the structure of the debt and the decision of the local government. ${ }^{17}$ The actions must be taken to correct any fundamental imbalance between responsibilities and resources. This also applies to the often murky financial relationship between municipal budgets and those of their utility companies and public service provider institutions (e.g. local public education, healthcare).

Within the Better Government Programme, the Ernst \& Young defined some standards for the debt management of local government which can be considered as a best practice and worth to be followed by the central and local governments.

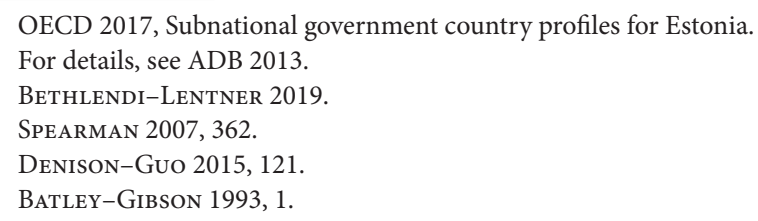


Table $\mathbf{1} \bullet$ Major areas and standards in debt management of local governments (Source: Compiled by the author based on BITNER-CICHOCKI 2008, 49.)

\begin{tabular}{|c|c|}
\hline Major areas & Management standards \\
\hline $\begin{array}{l}\text { Long-term financial } \\
\text { and investment } \\
\text { planning }\end{array}$ & $\begin{array}{l}\text { 1. Possession of a long-term financial plan (LFP) and long-term } \\
\text { investment plan (LIP) covering more than } 7 \text { years } \\
\text { 2. Possession of LFP/LIP approved by the council } \\
\text { (constitutive body) } \\
\text { 3. Possession of several versions of LFP/LIP } \\
\text { 4. Forecast of existing and future debt covering more than } 7 \text { years }\end{array}$ \\
\hline $\begin{array}{l}\text { Institutional and } \\
\text { organisational } \\
\text { management } \\
\text { methods }\end{array}$ & $\begin{array}{l}\text { 5. Permanent presence on the capital market } \\
\text { 6. Development of debt management policy (strategy) } \\
\text { 7. Designation of the unit (person) for debt management } \\
\text { 8. Possession of a rating } \\
\text { 9. Investor relations programme }\end{array}$ \\
\hline $\begin{array}{l}\text { Technical tools } \\
\text { for improving } \\
\text { management } \\
\text { effectiveness }\end{array}$ & $\begin{array}{l}\text { 10. Cooperation with an issuing house (lender) a) Bonds: } \\
\text { negotiated terms or underwriting b) Credit: assessment of } \\
\text { bids - effective cost or other criteria } \\
\text { 11. Broadening of local governments presence on the market } \\
\text { a) Bonds: public or non-public issue b) Credit: denominated in } \\
\text { local or foreign currency } \\
\text { 12. Management of financial risks inherent in raising outside } \\
\text { funds }\end{array}$ \\
\hline
\end{tabular}

Generally four debt management categories can be classified for the redemption: changing the conditions (lower interest cost - debt conversion, advance refunding debt consolidation, compromise), repayment strategies (terminal annuity, snowball or stacking method, debt management agency), additional resources (surplus, sinking fund, specialised financial institutions), and finally, state intervention (bailout - consolidation, limitations, financial guardian - insolvency administrator). 


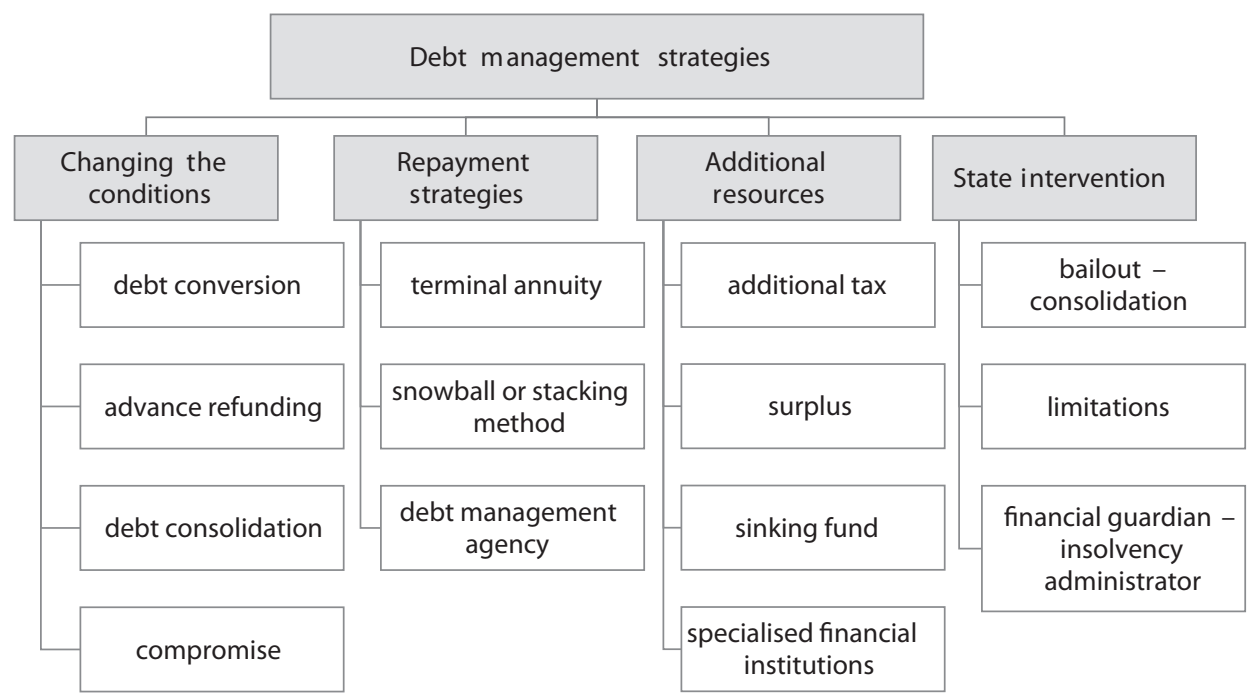

Figure 3 - Debt Management Strategies of Local Governments (Source: Compiled by the author)

\subsection{Changing the conditions}

First of all, it is important to emphasise that a change in the debt conditions (e.g. conversion, refunding, consolidation) does not mean repayment or redemption.

In the case of debts, the interest rate is a crucial point. In the beginning, it is worth reducing the interest cost even on loans and bonds, therefore the cost of the debt service will be lower for the local government, and ultimately for taxpayers, particularly for local citizens. Since local government loans and bonds are market priced, even the municipality can seize the opportunity when the market interest rates fall. This case is suitable for debt conversion, while the conditions of the higher interest rate can be converted into conditions with a new, lower interest rate. This method bears public benefit, because it reduces the burden of the debt service and the taxpayers, therefore this amount can be used for public expenditures. Moreover, tax cuts can be applied, which results in a reduction in the degree of inequality in the local distribution of income. Dalton calls attention to the fact that debt conversion does not really relax the debt burden, because a reduction in interest rate reduces the ability of bondholders to pay taxes, which may cause a reduction in public revenue, thereby reducing the capacity of the local government to redeem loans. ${ }^{18}$ Nevertheless, this holds true only if the bondholders are local taxpayers or national citizens, if they are foreigners, they may not be subject to the local taxes.

18 DALTON 1971 and 2013, 282-284. 
The advance refunding means that the local government exchange the loans or securities for a new loan or a loan secured with a longer maturity, usually for raising new funds in order to pay off the matured loans. The change of the maturity structure of the debt is generally a device for local economic stabilisation. This prolongs the average maturity structure of the existing local government debt, which tends to raise the interest rate. In the case of securities, they can become more attractive for the holders due to a higher yield. Since long-term local government bonds are not a good substitute for money, they increase the liquidity preference. Even in the banking system, the repayment is usually established through better conditions for the short term. There is a strong correlation between maturity and the debt burden because for the long term the local government should impose a higher tax burden on the taxpayers, or rearrange the expenditures in the local budget. Under this method, the financial burden of the local government debt is not relinquished but accumulated, owing to the postponement of debt redemption.

The debt consolidation method means that the local government takes out a new loan to pay off other debts. Consequently, this allows grouping all or the relevant part of the debt under one plan that has a single interest rate. Sometimes it could be easier to handle one relatively large monthly payment than to pay off multiple accounts. It can reduce management costs.

Finally, if bankruptcy has occurred, the negotiation of a compromise or a composition can be a solution, where the conditions, the maturity can be redefined. In this situation the goal of the proceeding is to grant a stay of payment for the debtor with a view to seeking an arrangement with creditors, or attempts to enter into a composition arrangement with creditors. The composition means the debtor's agreement with the creditors laying down the conditions for debt settlement, in particular on any allowances and payment facilities relating to the debt, the remission or assumption of certain claims, the approval of the debtor's program for restructuring and cutting losses, or any action deemed necessary to restore or preserve the debtor's solvency, including the duration of and the procedures for monitoring the implementation of the composition arrangement. ${ }^{19}$

\subsection{Repayment strategies}

A temporal, maturity strategy is that - in accordance with the fiscal year - the local government follows the practice of paying off the debt on the basis of a terminal annuity by equal annual installments. The burden of debt diminishes annually, and by the time of maturity it is fully paid off. This method facilitates the debt service for the planners and policy-makers, and is favourable even for the lenders. An important advantage of this is that it is not required to repay the entire principal on the maturity date defined in

19 See Act XLIX of 1991. 
the borrowing agreement, which could easily upset the balance, since the debt has been amortised during the period.

There are two main repayment methods concerning how the redemption can take shape during the debt management by different ranking based upon the amount or the rates. In the case of snowball method, the focus is on the loan with the lowest balance (amount), regardless of the interest rate. This is a very common approach to managing multiple debts, and can be attractive not just for the municipality, but politically for the voters, too, because the leaders can communicate the success. According to surveys, people naturally follow this process. ${ }^{20}$ The second one is the stacking method, which lists the debts in order from highest to lowest interest rate. It involves making minimum payments on all debts except the one with the highest rate of interest and putting all extra money to that highest rate debt. Once it is paid off, the municipality then shifts the focus to the next highest rate loan.

If the local government cannot handle its indebtedness, a debt management agency can provide such services, in which financial, legal, and administrative experts establish the strategy. In this, the role of local government angels (similar to business angels) could be important, who can prepare guidelines based upon a cluster analysis.

\subsection{Additional resources}

The most evident and simplest method of debt redemption for the local government is to impose additional taxes on local citizens and firms in order to pay off the old loan's principal and interests, or the bonds' yield. The new taxes can be introduced, or the tax rates can be raised to a higher level, only within the legal framework (especially the acts on local taxes). This measure is as much simple, at least as much criticised. Although the fiscal balance can be re-established, it may create dissatisfaction among the local taxpayers. The inequality in the distribution of income means that during the redistribution the bondholders and lenders are preferred to the taxpayers. By the taxation of new subjects (buildings, arable land) or activities (tourism, business activity) the competitiveness of the local government can decrease. Nevertheless, even Keynes, Hayek and Dalton recommended taxes on private property and wealth with progressive rates as a method of public debt redemption, with the explanation that this is the least real burden on the society, and reduces the degree of inequality in the distribution. ${ }^{21}$ Anyway, this is a burden for both the current local community and, in the long term, the future generation. Later it will transform into political deficit during the local elections, ${ }^{22}$ as the taxpayers express their opinions and judgement as voters.

In rare and exceptional situations with favourable conditions, local governments are able to generate a surplus in the local budget, when this higher amount can be utilised as

\footnotetext{
AMar et al. 2011.

Keynes 1940.; Hayek 1940.; Dalton 1923.

BASTIDA-BEYAERT-BENITO 2012.
} 
a prepayment in the case of loans, paying back another old debt, or buying back from the market (the creditors) their own bonds and securities. On the one hand, public expenditure can be reduced to create a budget with a surplus, which means less money for the local public services. The surplus can also be gained by additional taxes, which method was explained above. Finally, the local economy can perform better, or new transfers can be assigned by the central government, which usually rarely happens.

Otherwise, a local government may establish a separate fund known as the sinking fund for the purpose of debt management. Under this system, the municipality deposits a certain (fixed) percentage of its annual income into this in every year over an extended period of time (usually 10-15 years). By the time the debt matures, sufficient money gradually accumulates in this system for the redemption, and the burden of debt is spread evenly during the period. It works like a prudently created depreciation fund. Furthermore, the amount and the balance of the fund increases the creditworthiness of the municipality, inspires confidence among the lenders, or - as other benefits - it can be applied as a collateral for debt obligations of local government-owned companies, local firms, or socially underprivileged local citizens (e.g. large families). Another way to operate a sinking fund is to repurchase a fraction of the outstanding bonds (at a special call price - callable bonds) in the open market each year. In mainstream scholarship, Due and Musgrave support the sinking funds as the most systematic and best method of debt repayment or redemption. ${ }^{23}$ In a controversial method, the local government borrows a new loan and credit, and then proceeds it to the sinking fund. Even though Dalton opined that they need to be accumulated only out of the current revenue, not out of new loans. ${ }^{24}$

According to the OECD subnational government country profiles (2017), in some countries, state or local government-owned specialised financial institutions (SFI) were established for additional resources. They are similar to the sinking fund, but their activities are like banking transactions.

Table 2 EU member states with and without LG specialised financial institutions (Source: Compiled by the author based on OECD 2017 and NALAS 2011.)

\begin{tabular}{|c|c|}
\hline Countries with SFIs & Countries without SFIs \\
\hline $\begin{array}{c}\text { France, Italy, Portugal, Spain, } \\
\text { United Kingdom } \\
\begin{array}{c}\text { Denmark, Finland, Sweden } \\
\text { + Norway (not EU member) }\end{array}\end{array}$ & $\begin{array}{c}\text { Austria, Belgium, Bulgaria, Croatia, Czech } \\
\text { Republic, Cyprus, Denmark, Estonia, Germany, } \\
\text { Greece, Hungary, Ireland, Latvia, Lithuania, } \\
\text { Luxembourg, the Netherlands, Poland, Romania, } \\
\text { Slovakia, Slovenia }\end{array}$ \\
\hline
\end{tabular}

In France the Agence France Locale (France Local Agency) is fully-owned by the French local authorities themselves, and dedicated to their funding, distributing loans to their

\footnotetext{
MuKheRJEe 2003, 161.

24 DALTon 1971 and 2013, 278-279.
} 
members by raising funds on the capital markets (pooled financing). ${ }^{25}$ In Italy, the cities and provinces receive funding from a government agency called Cassa Depositi e Prestiti (Deposit and Consignment Office) ${ }^{26}$ A similar institution can be found in Portugal, where the Fundo de Apoio Municipal (Municipal Resolution Fund) was created to provide assistance to distressed municipalities. ${ }^{27}$ In Spain, the Fondo de Liquidez Autonómica (Regional and Autonomous Liquidity Fund) was established in $2012 .{ }^{28}$ In the Nordic countries, the four main municipal funding vehicles in some cases have a long history: KommuneKredit (Denmark, 1898), KBN Kommunalbanken (Norway, 1926), Kommuninvesti Sverige AB (Sweden, 1986), and Municipality Finance PLC (Finland, 1989). ${ }^{29}$ Despite their creation at different times, they share many similarities: ${ }^{30}$

- they are not-for-profit entities whose sole purpose is to provide sub-national governments with competitive funding;

- they hold large market shares of sub-national government lending in their respective countries: in Denmark, more than 90-95\%; in Finland, around 50\%; in Norway, 47\%; and in Sweden, 40\%;

- they are owned by the sub-central or the central government, and they benefit from various forms of "last resort" support mechanisms;

- they provide funding exclusively via the international bond markets, rather than via deposits;

- they have low-risk credit portfolios; their 100\% exposure to individual sub-central governments is mitigated by the strength of the Danish, Finnish, Norwegian and Swedish local government sectors.

Another example is the Public Works Loans Board, which is a statutory body that acts as a lending agent for sub-national governments in the UK, and the bulk of borrowing is channelled through this board. ${ }^{31}$ The Central and Eastern European countries usually handle a lower level of local government debt, therefore these institutions are not necessary for them.

\subsection{State intervention}

As it has already been mentioned, the central government/budget is not responsible for the local government debts, obligations or other consequences of the loss-making management. However, in some cases the central government bailout is the easiest way,

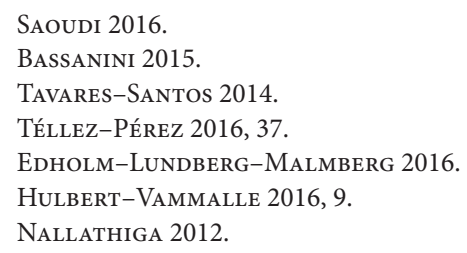


which is sometimes covered by the expression consolidation, as a euphemism..$^{32}$ In Hungary, the central government implemented a comprehensive consolidation between 2011 and 2014 in four phases, during which all the debts of the local governments were overtaken by the government in the course of the renewal of the local government system. Meanwhile, a task-based financing system was introduced and many public tasks were transposed from local level to the state administration, e.g. healthcare and public education, which was widely criticised in many respects. ${ }^{33}$ The re-division of tasks also narrowed the central governmental resources for local governments from 4.19 billion euros in 2010 to 2.20 billion euros in 2015. Finally, 2082 local governments were consolidated and the amount reached 4.56 billion euros. ${ }^{34}$ This amount was $2.78 \%$ of the GDP and $5.54 \%$ of the public debt in 2010. The Italian government set up a funding plan in 2013 to repay the subnational governments' accumulated liabilities (debt buyback); the municipalities are financed through the Cassa Depositi e Prestiti. ${ }^{35}$

Table 3 - Types of limitations on local government debt (Source: Compiled by the author based on OECD 2017 and NALAS 2011.)

\begin{tabular}{|c|c|c|}
\hline \multicolumn{2}{|c|}{$\begin{array}{c}\text { Balanced local budget } \\
\text { and/or a defined reduction goal }\end{array}$} & $\begin{array}{c}\text { Authorisation } \\
\text { of the borrowing }\end{array}$ \\
\hline $\begin{array}{c}\text { Austria, Estonia, Finland, } \\
\text { Greece, Italy, the Netherlands, } \\
\text { Poland, Portugal, Slovakia, } \\
\text { Spain, Sweden, UK - England, } \\
\text { Scotland and Wales }\end{array}$ & $\begin{array}{c}\text { Czech Republic, } \\
\text { Denmark, Germany, } \\
\text { Hungary, Ireland, } \\
\text { Latvia }\end{array}$ & $\begin{array}{c}\text { Belgium, Croatia, France, } \\
\text { Luxembourg, Slovenia, } \\
\text { UK - Northern Ireland, } \\
\text { Romania }\end{array}$ \\
\hline
\end{tabular}

Another method of state intervention is when the legislator - upon the initiative of the central government - defines limitations for the indebtedness of the local governments. These mean restrictions of the fiscal autonomy of local governments, and there is a possibility of political abuse, if the central government has enough power to commit discrimination among municipalities upon political grounds. But as an ultima ratio, they can prove to be useful to gain the sustainability of the general government debt, and to meet with the financial requirements of the Maastricht criteria. The limitations focus on a balanced local budget as well-defined reduction goals, ${ }^{36}$ or prescribe authorisation of the borrowing from the central government, or both of them are applied simultaneously. The different types of limitations are described in detail in the OECD subnational government country profiles (2017). Eastern European local governments are financially strongly dependent on central state transfers, therefore the deterioration of local government finances can be partially

\footnotetext{
DiETRICHSON-ELLEGÅRD 2015.

LENTNER 2019, 43.

STEINER 2016, 13-14.

KurTi 2014.

SPEARMAN 2007, 102-103.
} 
attributed to EU funds: the co-financing requirements place a huge financial burden on local governments which are already striving to find sufficient resources for the provision of local services. ${ }^{37}$

Based on the OECD subnational government country profiles, legal provisions for a balanced local budget and/or defined reduction goals can be found in Austria, where the Internal Stability Pact (2012) set a balanced budget prescription for all levels of government; in 2016 a structural balance rule was implemented, and all levels of government must reduce their level of debt by $1 / 20$ per year. ${ }^{38}$ In Estonia, limits for local debt were introduced from 2009 to 2012, and according to the Financial Management of Local Authorities Act (2011), ${ }^{39}$ the debt ceiling ranges from $60 \%$ to $100 \%$ of the current year; operational revenues depend on the self-financing capacity of the municipality. Local budgets in Finland must be balanced over a four-year period, and the Municipal Act (2015) introduced a central government spending limit on local governments. However, unfortunately this deteriorating fiscal position pushed the municipalities to increase borrowing. ${ }^{40}$ In Greece, under the Kallikratis reform, an Observatory for Financial Autonomy of the Local Government Organizations was launched, ${ }^{41}$ which ensures the balanced budgets with additional limits: interest payments for a given year cannot exceed $20 \%$ of ordinary annual revenues, and total debt must remain under $60 \%$ of total annual revenues. Municipalities can join the Special Economic Recovery Program. ${ }^{42}$ In 1999, Italy has introduced an Internal Stability Pact to ensure - e.g. with borrowing limits, prudential rules on bond issuing - that the financial situation of subnational administrations be consistent with the EU fiscal rules. The constitutional budget stability rule with the principle that the deficits can no longer be financed through debt was passed in $2012 .{ }^{43}$ In the Netherlands, the Sustainable Public Finances Bill (2013) stipulates that municipalities are subject to a balanced budget rule, and may borrow loans or issue bonds only to finance capital expenditure. ${ }^{44}$ In Poland, the Public Finance Act defines the balanced local current budgets and strengthens debt limitations requiring that the sum of loan instalments and interest payments must not exceed $15 \%$ of the total debt. ${ }^{45}$ From 2014 the debt limit based on gross savings (instead of the revenues) was calculated over a three-year period. In Portugal, the Local Finance Law (2013) introduced new rules for arrears, off-balance sheet liabilities and expenditure ceilings, and also strengthened the net debt ceilings and borrowing constraints. In Slovakia, the subnational governments must follow a balanced budget rule, as well as debt ceilings since $2005 .{ }^{46}$ The

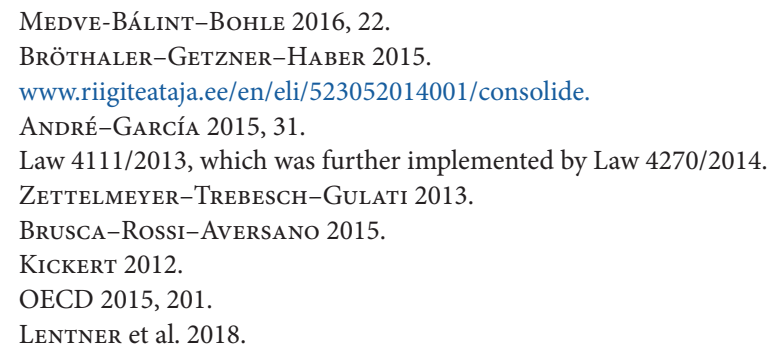


Fiscal Responsibility Constitutional Act (2011) and the Law on Budgetary Responsibility (2013) stipulated that local governments exceeding the debt limits must pay a fine imposed by the Ministry of Finance amounting to $5 \%$ of the difference between the total debt and the $60 \%$ ratio. In Spain, under the constitutional reform (2011), the fiscal consolidation was targeted for all the Spanish administration from 2020 onward. The Organic Law on Budgetary Stability and Financial Sustainability (2012) introduces a structurally balanced budget rule and debt ceilings, as well as expenditure rules. ${ }^{47}$ In Sweden, the municipalities and county councils are subject to a balanced budget requirement, they can borrow only to fund capital expenditure through bonds and loans. Within the United Kingdom, in England, Scotland and Wales, local governments are able to issue long-term debt to finance capital investments only. The local governments must follow the Prudential Code of the CIFPA (Chartered Institute of Public Finance and Accountancy), which sets indicators to be respected regarding affordability, sustainability and prudence.

In France, a preliminarily required authorisation for the borrowing can be found, the subnational governments are not able to borrow without approval from the central government, and long-term borrowing is restricted to finance investment. Belgium has an internal stability pact covering the period 2015-2018 and co-ordination mechanisms established by the Cooperation Agreement in 2013 to implement the Fiscal Compact. Regions and communities can borrow and issue debt on financial markets, although they require authorisation from the Federal Minister of Finance; municipalities and provinces are free to borrow, but only to fund investment projects. ${ }^{48}$ In Luxembourg, any local loans in excess of 50,000 euros must be approved by the Ministry of the Interior. Borrowing is only allowed if there is no other financing option, the regular reimbursement of annual accruals is guaranteed, and loans are only permitted to fund capital expenditure. In Slovenia, according to the Public Finance Act (1999) and the Financing of Municipalities Act (2006), municipalities have the right to borrow to finance certain types of investment projects only with the prior consent of the Ministry of Finance. ${ }^{49}$ "In Northern Ireland within the United Kingdom, borrowing is subject to approval by the Ministry of the Environment and must aim at financing capital projects only." ${ }^{50}$

For dual limitation, balanced budget and authorisation rules are typical in the Czech Republic, where a new fiscal framework is under preparation for regulating local government indebtedness. This requires that the level of local gross debt remains below $60 \%$ of a fouryear average of revenues. The bond issuance must be approved by the Ministry of Finance. In Denmark, with the Budget Law (2012) a balanced budget rule and a multiannual binding expenditure ceiling were introduced, and the borrowing is subject to the supervision and approval of the central government. In Germany, the balanced structural budget provisions and a "debt brake rule" were introduced in 2011 at the federal and Länder levels following

\footnotetext{
BRUSCA-Rossi-AvERSANO 2015.

JENNES 2014.

OpLOTNIK-BREZOVNIK-VOJINOVIĆ 2012.

OECD 2020, 116.
} 
the 2009 constitutional reform. Local governments must balance their budgets and have borrowing restrictions, all must have the approval of the supervisory authority. ${ }^{51}$ Another example is Hungary, where the Fundamental Law and the Economic Stability Act (2011) states the principle of sustainable budgeting and prescribes certain conditions for any borrowing by local governments to the extent determined in the Stability Act, ${ }^{52}$ and/or the consent of the Government is required..$^{53}$ The Act on Local Government prohibits the planning of operational deficit in the Financial Regulation. In Ireland, the government in 2004 and 2009 set a limit of 200 million euros for contribution to the local government sector in any one year. The Local Government Reform Act (2014) states that a local authority may borrow money in any manner it considers suitable for the effective performance of its functions, but it needs prior approval of the central government. ${ }^{54}$ In Latvia, local governments can only carry out long-term borrowing to finance investment projects, and the loans must be contracted with the State Treasury or within specific funding programmes, or borrowing from another institution must be justified and authorised by the Ministry of Finance. The borrowing in a given year cannot exceed $20 \%$ of current revenues.

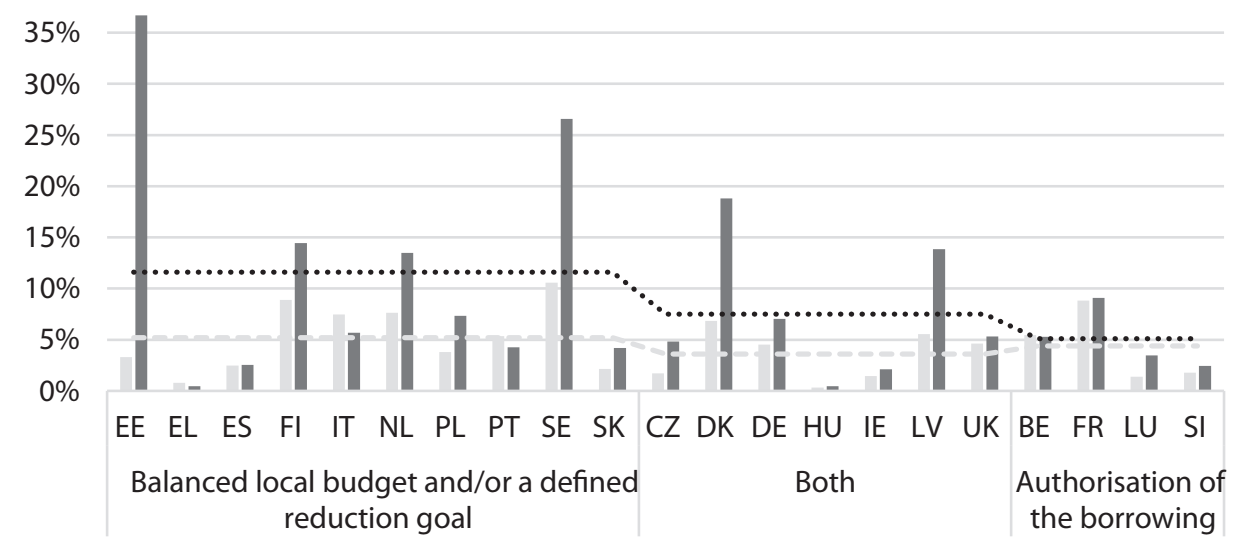

LG debt \% GDP LG debt \% public debt Av. \% GDP Av. \% public debt

Figure 4 - Types of limitation and the local government debt in \% of GDP and \% of public debt (Source: Compiled by the author based on OECD 2017)

\footnotetext{
FosSEN-FreIER-Martin 2014.

HEgEDÜS-LENTNER 2020.

53 Nyıкos 2013; The Fundamental Law of Hungary Article 34 Paragraph (5), Act CXCIV of 2011 on the economic stability of Hungary Article 10-10/D; 353/2011. (XII. 30.) Government decree on the detailed rules for the consent to debt-generating transactions.

54 Local Government Reform Act 2014 Article 106 S.I. No. 215 of 2014, which modified the Local Government Act 2001.
} 
All the three solutions are followed by numerous countries, most of them apply the rules on balanced local budget and/or defined reduction goals, while the authorisation of borrowing is also popular. Unfortunately, there is no correlation between the regulation method and the results in local government debts, because in each group some outstanding value can be found. But it can be observed that the average is the lowest in the authorised borrowing with a balanced budget prescription method (3.6\% of the GDP, but $7.5 \%$ of the public debt). Despite these figures, the authorisation reduces the average in the case of the public debt (5.1\%), but remains higher relative to the GDP (4.4\%). It is highest in the solely balanced budget group (5.2\% of the GDP and $11.6 \%$ of the public debt).

Another exceptional resolution is when for ultimate debt management a financial guardian or an insolvency administrator is delegated to the local government by the central government to conduct the debt settlement procedure. Since this procedure is similar to bankruptcy proceedings, it should be under the supervision of the relevant court, e.g. ordinary court, administrative court or registry court. This process may be initiated by either the local government or its creditor(s). The financial guardian monitors the management of the local government, reveals the reasons for the indebtedness, has access to all documents relating to the assets of the local government, prepares a referral on debt settlement, initiates the recovery of the overdue receivables, contacts with the creditors, carries out the duties and powers mandated by the law. Upon the results of the monitoring, the local government (or a debt settlement committee) establishes a crisis budget and financial plan, and in the case of insolvency, a proposal for compromise. In Hungary, separate legislation defines the specific regulation. ${ }^{55}$

\section{CONCLUSIONS}

While a considerable part of public debt originates from the budgetary practices of municipalities, the amount of local government debts is not a major problem in the European countries. The average local debt ratio is approximately $3.8 \%$ of the GDP and $6.7 \%$ of the public debt. Therefore, it is not a significant macroeconomic obstacle for most of the EU member states to meet the Maastricht criteria. Only a few countries are faced with difficulties: Estonia, Sweden, Denmark in the proportion of the general government debt, and Finland and France in relation to the GDP. The total local debt amounts to nearly 850 billion euros, the four-fifths of which belongs to six countries (France, Germany, Italy, the United Kingdom, the Netherlands and Sweden). An overwhelming proportion of it is denominated in loans since it is simpler and easier for municipalities to borrow money from the financial intermediaries, and they are able to provide suitable coverages. It can be observed that according to the structure of the LAU 2 level, in countries with larger and more populous local governments (the United Kingdom, Denmark, the Netherlands or

55 For details, see Act XXV of 1996 on the debt settlement procedure of local governments. 
Sweden) the sum of the local government debt is not so high, but for a single municipality or for a local citizen, it still means a higher burden.

The purpose of debt management is the redemption, which has many different ways, and it is difficult to generate a satisfactory general theory for it. The golden principle states that the consequences of the loss-making management of the local government are borne by the local government, and the central budget is not responsible for its obligations. Four debt management categories can be classified: changing the conditions (debt conversion, advance refunding, debt consolidation, compromise); repayment strategies (terminal annuity, snowball or stacking method, debt management agency); additional resources (surplus, sinking fund, specialised financial institutions); and finally, state intervention (bailout - consolidation, limitations, financial guardian - insolvency administrator).

Unfortunately, there are no good or best practices for the first two methods, since they are closer to the business sphere, and municipalities have not enough financial and fiscal potential to rearrange the local budget. For additional resources, in some Mediterranean (France, Portugal, Spain, Italy) and Nordic countries (Sweden, Denmark, Finland, Norway), state or local government-owned specialised financial institutions were successfully established. In other European countries, unsustainable local government debt has emerged as a problem, and finally, the state pays the bailout or consolidation by overtaking the debt. In another form of state intervention, the legislator - upon the initiative of the central government - defines limitations. These restrict the fiscal autonomy of local governments, but as an ultima ratio, they can prove to be useful to gain the sustainability of the general government debt. The limitations focus on two main areas: a balanced local budget as a well-defined reduction goal, or a prescribed authorisation of the borrowing from the central government. In five countries, both of them are applied simultaneously. Finally, in most cases, only the direct and/or indirect state intervention methods were proven to be successful solutions. 


\section{REFERENCES}

1. Abad, Pilar - Chuliá, Helena - Gómez-Puig, Marta (2010): EMU and European government bond market integration. Journal of Banking \& Finance Vol. 34, No. 12. 2851-2860. DOI: https://doi.org/10.1016/j.jbankfin.2009.10.009

2. Aczél Ákos - Homolya Dániel (2011): Risks of the indebtedness of the local government sector from the point of view of financial stability. MNB Bulletin, October 2011. 7-14.

3. Amar, Moty-Ariely, Dan - Ayal, Shahar-Cryder, Cynthia E. - Rick, Scott I. (2011): Winning the Battle but Losing the War: The Psychology of Debt Management. Journal of Marketing Research, Vol. 48. 38-50. DOI: https://doi.org/10.1037/e722992011-091

4. Bassanini, Franco (2015): La politica industriale dopo la crisi: il ruolo della Cassa Depositi e Prestiti. L'industria: rivista tecnica ed economica illustrata, Vol. 36, No. 3. 435-454.

5. Bastida, Francisco - Beyaert, Arielle - Benito, Bernardino (2012): Electoral Cycles And Local Government Debt Management. Local Government Studies, Vol. 39, No. 1. 107-132. DOI: https://doi.org/10.1080/03003930.2012.683861

6. Batley, Richard - Gibson, John (1993): Financing European Local Government. London, Routledge. DOI: https://doi.org/10.4324/9781315037271

7. Bethlendi András - Lentner Csaba (2019): A magyar önkormányzati eladósodás és válságkezelés nemzetközi összehasonlításban. Közgazdasági Szemle, Vol. 66, No. 10. 1013-1030. DOI: https://doi.org/10.18414/ksz.2019.10.1013

8. BRöthaler, Johann - Getzner, Michael - Haber Gottfried (2015): Sustainability of local government debt: a case study of Austrian municipalities. Empirica, Vol. 42, No. 3. 521-546. DOI: https://doi.org/10.1007/s10663-014-9261-3

9. Brusca, Isabel - Rossi, Francesca Manes - Aversano, Natalia (2015): Drivers for the Financial Condition of Local Government: A Comparative Study Between Italy and Spain. Lex Localis - Journal of Local Self-Government, Vol. 13, No. 2. 161-184. DOI: https://doi.org/10.4335/13.2.161-184(2015)

10. Dalton, Hugh (1923): The Capital Levy Explained. London, Labour Publishing.

11. Dalton, Hugh (1971 and 2013): Principles of Public Finance. London, Routledge. DOI: https://doi.org/10.4324/9781315016948

12. Denison, Dwight V. - Guo, Zihe (2015): Local Government Debt Management and Budget Stabilization. In Hou, Yilin ed.: Local Government Budget Stabilization. Cham, Springer. 121-139. DOI: https://doi.org/10.1007/978-3-319-15186-1_7

13. Dietrichson, Jens - Ellegård, Lina Maria (2015): Assist or desist? Conditional bailouts and fiscal discipline in local governments. European Journal of Political Economy, Vol. 38. 153-168. DOI: https://doi.org/10.1016/j.ejpoleco.2015.02.004

14. Dzigbede, Komla D. (2016): Essays in State and Local Government Debt Management: Networks, Strategic Refinancing and Regulatory Disclosure. Dissertation, Georgia State University. 
15. Finžgar, Mateja - Brezovnik, Boštjan (2019): Direct international comparison of EU member states fiscal decentralization systems with the Conceptual Index of Fiscal Decentralization (CIFD) in the Context of European Charter of Local SelfGovernment (ECLSG). Transylvanian Review of Administrative Sciences, No. 56E. 41-59. DOI: https://doi.org/10.24193/tras.56e.3

16. Fossen, Frank M. - Freier, Ronny - Martin, Thorsten (2014): Race to the Debt Trap? - Spatial Econometric Evidence on Debt in German Municipalities. DIW Berlin Discussion Paper No. 1358. Berlin, German Institute for Economic Research. DOI: https://doi.org/10.2139/ssrn.2383807

17. Hayek, Friedrich (1940): Review of John Maynard Keynes: How to Pay for the War. Economic Journal, Vol. 50. 321-326. DOI: https://doi.org/10.2307/2226138

18. Hegedüs Szilárd - Lentner Csaba (2020): Comparative Analysis of Budgetary Indicators of European Municipal Subsystems in the Post-Crisis Term between 2009-2018. Pénzügyi Szemle (Public Finance Quarterly), Vol. 65, No. 1. 112-133. DOI: https://doi.org/10.35551/pfq_2020_1_8

19. Keynes, John Maynard (1940): How to Pay for the War: A Radical Plan for the Chancellor of the Exchequer. London, Macmillan and Co. Ltd.

20. Kickert, Walter (2012): State Responses to the Fiscal Crisis in Britain, Germany and the Netherlands. Public Management Review, Vol. 14, No. 3. 299-309. DOI: https://doi. org/10.1080/14719037.2011.637410

21. Kurti, Teki (2014): Financial System and the Local Government in European Countries. European Scientific Journal, Vol. 1 (special ed.). 543-547.

22. Lentner Csaba (2019): Önkormányzati pénz-és vagyongazdálkodás. Budapest, Dialóg Campus.

23. Lentner Csaba - Hegedüs Szilárd (2019): Local Self-Governments in Hungary: Recent Changes through Central European Lenses. Central European Public Administration Review, Vol. 17, No. 2. 51-72. DOI: https://doi.org/10.17573/cepar.2019.2.03

24. Lentner Csaba - Nagy László - VAsa László - Hegedüs Szilárd (2018): Comparative analysis of the process for compliance with the European Charter of Local SelfGovernment in The Czech Republic, Hungary and Slovakia - with special emphasis on economic conditions and Hungarian atypical features. Economic Annals-XXI, Vol. 173, No. 9-10. 10-18. DOI: https://doi.org/10.21003/ea.v173-02

25. Lentner Csaba - NAgy László - VASA László - Hegedüs Szilárd (2019): Sustainability and Control Issues of the Financial Management of Local Governments - Through Hungary's Example. Visegrad Journal on Bioeconomy and Sustainable Development, Vol. 8, No. 1. 18-26. DOI: https://doi.org/10.2478/vjbsd-2019-0004

26. Mukherjee, Sampat (2003): ISC Economics. London, Allied Publishers.

27. Nallathiga, Ramakrishna (2012): The System of Local Government Finance: A Study of Select Countries. NIFM Journal of Public Financial Management, Vol. 4, No. 2.

28. Nyıkos Györgyi (2013): Fiskalregeln als Instrumente für einen nachhaltigen Haushalt in Ungarn. In ECKARDT, Martina - PÁllinger Zoltán Tibor eds: Schuldenregeln als 
goldener Weg zur Haushaltskonsolidierung in der EU? Budapest, Nomos. 141-157. DOI: https://doi.org/10.5771/9783845245065-141

29. Oplotnik, Zan Jan - Brezovnik, Bośtjan - Vojinović, Borut (2012): Local SelfGovernment Financing and Costs of Municipality in Slovenia. Transylvanian Review of Administrative Sciences, No. 37E. 128-142.

30. Spearman, Kay (2007): Financial Management for Local Government. London, Routledge. DOI: https://doi.org/10.4324/9781849771320

31. Stelmach, Jerzy - Brozek, Bartosz (2006): Methods of Legal Reasoning. Cham, Springer. DOI: https:/doi.org/10.1007/1-4020-4939-0

32. Tavares da Silva, Suzana - Santos, Marta Costa (2014): O Fundo de Apoio Municipal - algumas considerações. Questões Atuais de Direito Local, No. 4. 33-52.

33. Vértesy László (2019): Local Debt Burden at LAU2 level in the EU countries. In NeŠleha, Josef et al. eds.: European Financial Systems 2019. Proceedings of the 16th International Scientific Conference. Brno, Masaryk University. 616-624.

34. Zettelmeyer, Jeromin - Trebesch, Christoph - Gulati, Mitu (2013): The Greek debt restructuring: an autopsy. Economic Policy, Vol. 28, No. 75. 513-563. DOI: https:// doi.org/10.1111/1468-0327.12014

\section{Internet sources}

1. ADB (2013): Local Debt in the People's Republic of China: Local Government Financing Vehicle's Debt Management and Risk Control - Replacing Shadow Bank Financing with Local Government Bond. Asian Development Bank, Technical Assistance Consultant's Report. Available: www.adb.org/sites/default/files/project-document/79814/45157001-tacr-02.pdf (Downloaded: 08. 07. 2020.)

2. André, Christophe - García, Clara (2015): Local Public Finances and Municipal Reform in Finland. OECD Economics Department, Working Paper No. 1121. DOI: https://doi.org/10.1787/5jz2qt0zj024-en

3. Bitner, Michał - Cichocki, Krzysztof S. (2008): Effectiveness of debt management in local governments. Program Ernst \& Young, Warsaw. Available: www. ey.com/Publication/vwLUAssets/Effectiveness_Debt_Management.pdf/\$FILE/ Effectiveness_Debt_Management.pdf (Downloaded: 08. 07. 2020.)

4. Davey, Kenneth ed. (2011): Local Government in Critical Times: Policies for Crisis, Recovery and a Sustainable Future. Council of Europe. Available: www.ccre.org/docs/ Local_Government_in_critical_times.EN.pdf (Downloaded: 08. 07. 2020.)

5. Edholm, Zacharias - Lundberg, Kevin - Malmberg, Jonathan (2016): Finansiella marknadsprogram i kommunal sector. Örebro universitet, Handelshögskolan. Available: www.diva-portal.org/smash/get/diva2:949531/FULLTEXT01.pdf (Downloaded: 08. 07. 2020.)

6. Eurostat (2016): Manual on Government Deficit and Debt - Implementation of ESA 2010. DOI: https://doi.org/10.2785/844106 
7. Hulbert, Claudia - Vammalle, Camila (2016): Monitoring Sub-central Governments' Debts: Practices and Challenges in OECD Countries. OECD - RIFDE, Papeles a discusión 1/2016. Available: www.rifde.es/documentos/papeles/01_Monitoring_ Sub-central_Governments_Debts.pdf (Downloaded: 08. 07. 2019.)

8. Jennes, Geert (2014): Has Belgian Fiscal Decentralisation Reduced the Size of Government and the Budget Deficit? SRNN, January 2014. DOI: https://doi.org/10.2139/ ssrn.2387374

9. International Monetary Fund (2013): Public Sector Debt Statistics: Guide for Compilers and Users. Available: http://tffs.org/pdf/method/2013/psds2013.pdf (Downloaded: 08. 07. 2020.)

10. Local government debt. Eurostat, 2018. Available: http://appsso.eurostat.ec.europa.eu/ nui/show.do?dataset=gov_10dd_logd\&lang=en (Downloaded: 22. 05. 2019.)

11. Medve-BÁlint Gergő - Bohle, Dorothee (2016): Local Government Debt and EU Funds in the Eastern Member States: The Cases of Hungary and Poland. MaXCaP Working Paper Series, No. 33, September. Available: http://real.mtak.hu/73214/1/ wp_33.pdf (Downloaded: 08. 07. 2020.)

12. NALAS (Network of Associations of Local Authorities of South-East Europe) (2011): Guidelines on Local Government Borrowing in South East Europe. NALAS. Available: www.nalas.eu/knowledge-center/Guidelines-on-Local-Government-Borrowing (Downloaded: 08. 07. 2020.)

13. OECD (2015): The State of Public Finances 2015. Strategies for Budgetary Consolidation and Reform in OECD Countries. Available: www.oecd.org/governance/the-state-ofpublic-finances-2015-9789264244290-en.htm (Downloaded: 08. 07. 2020.)

14. OECD (2017): Subnational government country profiles (for Austria, Belgium, Czech Republic, Denmark, Estonia, Finland, France, Germany, Greece, Hungary, Italy, Latvia, Luxembourg, Poland, Portugal, Slovakia, Slovenia, Spain, Sweden, United Kingdom). OECD.Stat. Available: https://stats.oecd.org/Index.aspx?DataSetCode=SNGF (Downloaded: 02. 02. 2020.)

15. OECD (2020): Urban Policy Reviews, Enhancing Productivity in UK Core Cities. Available: www.oecd.org/unitedkingdom/enhancing-productivity-in-uk-core-cities9ef55ff7-en.htm (Downloaded: 13. 08. 2020.)

16. SaOudi, Messaoud (2016): Un nouvel instrument financier de développement des territoires. L’Agence France locale, CIST2016 - En quête de territoire(s)? Collège international des sciences du territoire (CIST), Grenoble, France. Available: https:// hal.archives-ouvertes.fr/hal-01353682/document (Downloaded: 08. 07. 2020.)

17. Schnyder, Gerhard (2016): The Law and Finance School: What Concept of Law? SRNN, October 27. DOI: https://doi.org/10.2139/ssrn.2859950

18. Steiner Erika (2016): Introduction to the Hungarian Local Government System. Hungarian Association of Local Governments - Norway Grants. Available: www. manorka.net/uploads/images/Kiadv\%C3\%A1nyok/Local\%20Governments_ boritoval.pdf (Downloaded: 08. 07. 2020.) 
19. Structure of government debt. Eurostat, 2020. Available: https://ec.europa.eu/eurostat/ statistics-explained/index.php/Structure_of_government_debt (Downloaded: 13. 08. 2020.)

20. Téllez, Mar Delgado - Pérez, Javier J. (2016): La financiación de las comunidades autónomas más allá del sistema de financiación autonómica. Fedea Policy Papers -2016/22. Banco de España. Available: http://documentos.fedea.net/pubs/fpp/2016/10/ FPP2016-22.pdf (Downloaded: 08. 07. 2020.)

Dr. habil. László Vértesy PhD jur. PhD œc. is an associate professor at the University of Public Service Faculty of Public Governance and International Studies Lörincz Lajos Department of Administrative Law. His research interests focus on the relationship between law and finance, financial law, banking law and administrative law, as well as in economics macroeconomics, financial industries (banking, insurance, stock market), monetary and fiscal policy, and economic activity. Since 2005 he has been constantly teaching in the Hungarian and foreign higher education, presenting lectures, participating in international conferences. In addition, he performs research, consulting and legal tasks in several scientific institutions and companies. More than 130 English and Hungarian publications of his have appeared. In 2020, his monograph entitled Law and Finance in the Banking Sector was published by Akadémiai Kiadó. He is a member of the public body of the Hungarian Academy of Sciences, a member of the Hungarian Bar Association, a professional director of the Klebelsberg Kunó College in Oradea, and a vice-president of the Carpathian Youth Association. 